\title{
A COMPARATIVE STUDY BETWEEN THE USE OF BLOCK STYLE AND POINT BY POINT METHOD ON WRITING ABILITY
}

\author{
Muhammad Taufik Ihsan \\ State Islamic University of Sultan Syarif Kasim Riau, Indonesia \\ muhammadtaufikihsan@gmail.com
}

\begin{abstract}
This main aim of this research was to find out whether there is any significant difference between students' writing ability on using block style method and students' writing ability on using point by point method. The design of this research is a causal-comparative study that focusing on quantitative research. The subject of this research was level 2 students' of language center UIN Suska Riau. The object of this research was comparing between using block style and point by point method on students' writing ability. The sample was two classes; Experiment class (34 students) and compare class (34 students). The total sample was 78 students by using cluster sampling. The test and questionnaire were used to collect the data and data was anlyzed by using compare means and t-test by using SPSS 20.0. the last finding of this research was found that there was a signifficant difference on students' writing ability between using block style and point by point method. It shown on comparing the mean score. Block style method was 60.7353 and point by point method was 78.3824. And the hyphothesis testing was show the result of post T-test 11.823, then score of sig.(2-tailed) is 0.000 . if we act to null hypothesis $\left(\mathrm{H}_{\mathrm{o}}\right)$ that is 0.05 , it means that the score of sig.(2-tailed) was smaller than score of $\mathrm{H}_{\mathrm{o}}$. Therefore, the null hypothesis was rejected and the alternative hypothesis was accepted. It means that there is a significant difference between The Use of Block Style Method and Point by Point Method on The Students' Writing Ability at Language Center of UIN Suska Riau. At last, it shows that Point by point was better compared to the implementation of Block Style Method.
\end{abstract}

Keywords: Block style method, Point by point method, Writing ability.

\section{INTRODUCTION}

In Indonesia, English gives some very meaningful contributions to the development especially in tourism, business, science and technology. Because of that, our government has determined English to be taught in all levels of education in our country starting from elementary school to university. At Elementary school, English is taught as a local content from year 1 to year four, and at year 4 upto year 6 , it is taught as a compulsory subject. At junior and senior high school, English is taught as a 
compulsory subject within four classhours a week. The main goal of teaching English is to master four language skills and language componenets like vocabulary and grammar. (Depdiknas: 2005).

Four language skills that the students must intend to master in learning English are listening, speaking, reading, and writing. Writing has been recognized that specific ability which helps writers to put their thoughts into words in a meaningful form and to mentally interact with the message. Olice Oshima and Ann Hogue (1999: 3) state that writing is a process of formulating and organizing ideas in right words to deliver the aim and present them on a piece of paper. Writing is also a powerful instrument for students to use to express their thoughts, feelings, and judgments about what they have read, seen or experienced. In addition, they claim that in particularly academic writing is not easy. It takes study and practice to develop this skill. Therefore, the students must consider that writing is a habit in their daily live.

The importance of writing for the students is to make them understand that writing is an essential part of one's life for communicating and get satisfy personal and academic needs, to recognize the students that oral language needs to be adapted for specific purposes such as communication messages for a variety of activities and events, to continue the students enjoying writing and understand that writing can be used for a variety of purposes. The students can also write a variety of simple and complex sentences grouped into paragraphs. Simon and schuster (1978)

The principles for teaching writing, Nation (2008:93) states that a writing course or the writing section of the language can be used to make sure that learners are getting a good range of opportunities for learning. Within each strand the principles are ranked with the most important principle first.

There are two meaning-focusses. Firstly, meaning-focus input is that learners should bring experience and knowledge to their writing. And secondly, meaning-focused output is that learners should write with a massage-focused purpose, writing should interest learners and draw on their interests. In language-focused learning, learners should recognize about the parts of the writing process and should be able to discuss them in the relation to their own and other writing. In fluency development, learners should increase their writing speed so that they can write very simple material at a reasonable speed.

In writing, there are many kinds of paragraph. They are definition, classification, description, compare and contrast, sequence, choice, explanation, evaluation, etc. According to Simon and schuster ( 1978 : 179), One of the best ways to make your writing interesting and informative is to develop a subject by means of comparison or contrast. Comparison shows similarities between persons, places, things, ideas, or situations. Contrast does just the opposite; it points out the differences between persons, places, things, ideas, or situations. Wheter you organize material for a comparison or for a contrast, however, your methods are essentially the same.

The students find comparecontrast writing more difficult than other expository formats (Hiebert, Englert, \& Brennan, 1983). The difficulties include problems with acquiring source information, with 
organizing information into comparecontrast format, or both. There are several things to remember in writing controling idea for a comparison or contrast paragraph. First, remember that the writers' have two subject; therefore, the topic sentence must be carefully worded to show not only the attitude, but also the kind of comparison or contrast. Second, the writers must have some short of point to make beyond a simple description of the two things they are comparing (Simon and schuster, $1978: 180$ ).

Students read two descriptive passages and wrote a compare-contrast essay. Students receiving Text Structure instruction had significantly higher scores on compare-contrast Structure but lower ones on Content than did those in the other groups. Students receiving Summarization Skills instruction had significantly lower scores on Structure than did students in the other groups. Explicit instruction in text structure is recommend for compare-contrast writing, including specific strategy instruction to match learning goals and tasks. Further research is recommended about the interaction of content knowledge and writing strategy knowledge, as well as the role of text structure in readingwriting expository text.

In writing, when it is decided on two subjects, the next point for consideration is the basis (bases) for its comparison or contrast. To be meaningful, the basis must be identical for both subjects: if comparing two steaks, for instance, the writer can not evaluate one on its price and the other on its flavor. Or if in discussing two movies, Movie A and Movie B, the writer talks about the similarities of script, the acting, and the cinematography of Movie A and B, then he/she needs to discuss the differences of script, the acting, and the cinematography of Movie A and B.

Based on preliminary study conducted at State Islamic University (UIN) SUSKA Riau, Teaching languages like English and Arabic are administered 3 levels at Language Center. All of the students at Language Center of UIN SUSKA RIAU should pass all levels. In learning English, one of the skills taught is writing. They get difficulties how to compose it Eventhough the students have learned writing for 3 levels. They already learn about writing compare and contrast essay. So, the researcher looking for the comparison ability of students' in writing compare and contrast essay.

There are two type of writing compare and contrast essay. There are block style method and Point by point method. The procedure writing block style method: In this structure, you say everything about one item then everything about the other. For instance, say everything about the characters, setting, and plot for the book then everything about the characters, setting, and plot for the movie. Whole-to-Whole comparison and contrast uses a separate section or paragraph for each item you're discussing. 


\begin{tabular}{|l|}
\hline Introduction \\
\hline Item 1 \\
\hline Item 2 \\
\hline Conclusion \\
\\
\end{tabular}

For a paper comparing and contrasting a book to a movie, the section for Item \#1 would include everything about the book and the section for Item \#2 would cover everything about the movie. The points in each of the sections should be the same and they should be explained in the same order (for instance, you might discuss character, setting, and plot for both, and in that order for both).
It is differ than writing essay by using Point by point method, the procedure is: Point by Point Method is a compare and contrast of one point of a topic with a point of the other topic

\begin{tabular}{|c|c|}
\hline Advantages & $\begin{array}{l}\text { Keeps each set of } \\
\text { points for } \\
\text { discussion close } \\
\text { together The reader } \\
\text { does not have to } \\
\text { remember as much } \\
\text { information Keeps } \\
\text { the paper clearly } \\
\text { organized Avoids } \\
\text { summary }\end{array}$ \\
\hline Disadvantages & $\begin{array}{l}\text { Can appear } \\
\text { mechanical and } \\
\text { monotonous Does } \\
\text { not provide a } \\
\text { unified discussion } \\
\text { of the two sides }\end{array}$ \\
\hline
\end{tabular}

The Point-by-Point method alternates arguments about the two items (A and B) that you are comparing and/or contrasting. The pattern is as follows:

- Point 1 - discuss A

- Point 1 - discuss B

Discussion about overall links between A and B

- Point 2 -discuss A
- Point 2 - discuss B

- Discussion about overall links between $\mathrm{A}$ and $\mathrm{B}$

This method is often easier for a reader to follow because similarities and differences are more obvious when placed next to each other. For this reason, writers generally use this method for longer essays.

\section{METHOD}

The design of the research is a causal-comparative study that focuses on quantitative research. According to L. R Gay (2000: 364), the causalcomparative design involves selecting two groups differing on some independent variables and comparing them on some dependent variable. The groups may differ in a number of ways. One group may possess a characteristic that the other does not, one group may possess more of a characteristic than the other, or the two groups may have had different kind of experiences. In this research, there are three variables; block style method and point by point method are independent variables, while the students' writing ability is dependent variable. Therefore the experimental class is provided with the treatment, and post-test.

The Research Design

\begin{tabular}{cccc}
\hline E1 & - & X1 & O \\
C & - & X2 & O \\
\hline
\end{tabular}


E1 : Experimental Group 1

C : Compare Group

X1 : Independent variable 1 (Block Style Method)

$\mathrm{X} 2$ : Independent variable 2 (Point by Point Method)

$\mathrm{O}$ : Post-test

This research conducted at Language Center of UIN SUSKA RIAU. It is located at Jl. KH. Ahmad Dahlan no. Sukajadi. The duration of time to conduct of this research is within two months starting April to May 2015. Since it is a pre - experimental research design that has certain purpose, the researcher used random cluster sample technique. It consisted of two group taught by using different treatments; the researcher took two classes in which they were as group 1 and group 2. One group consists of 34 students. According to Gay, (2000: 129). Cluster sampling is a sampling in which group, not individuals, are randomly selected. All the members of selected groups have similar characteristics.

\section{Research Procedure}

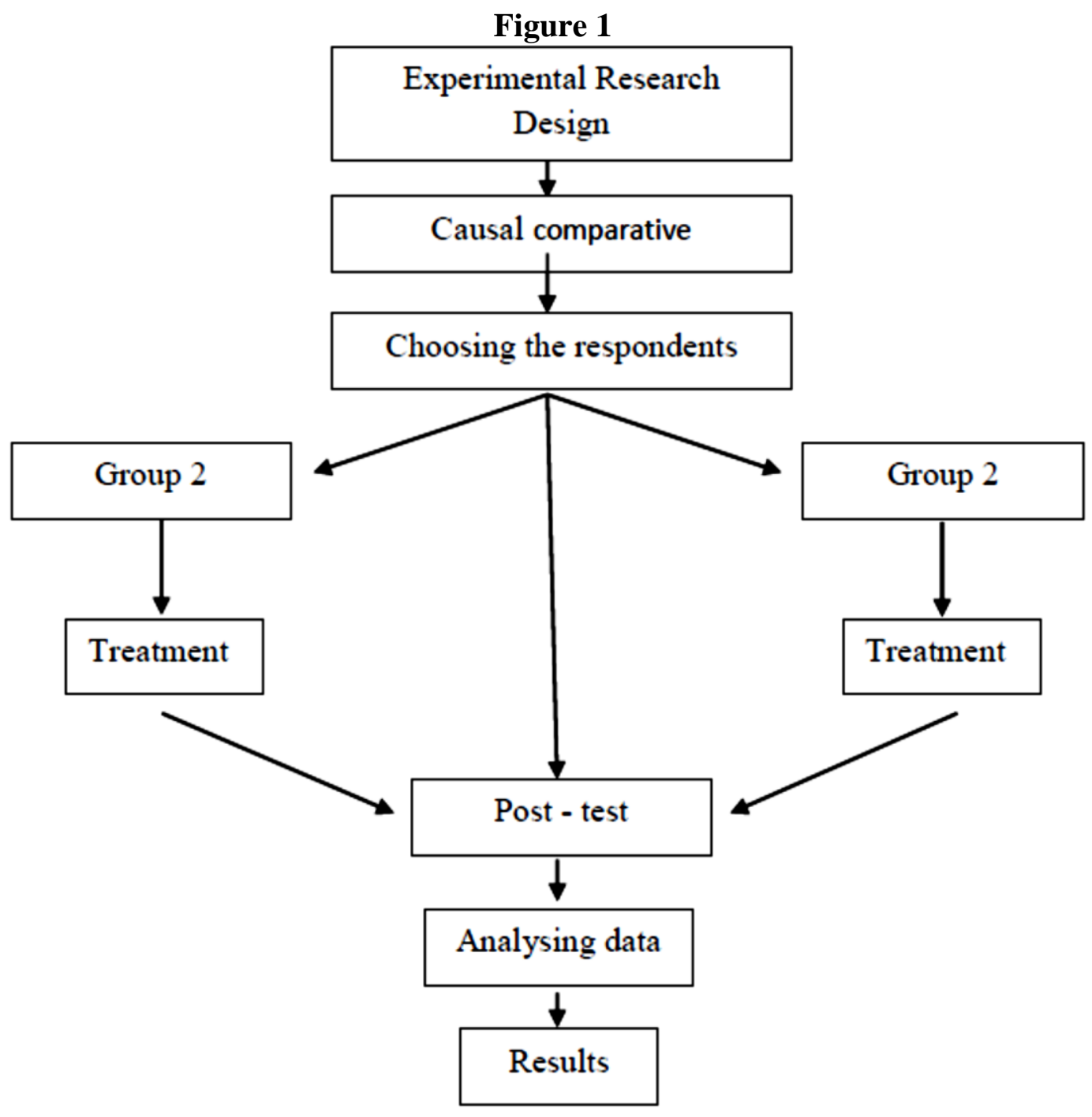




\section{RESULTS AND DISCUSSION}

The result of the writing test using Block style and Point by Point methods according 2 raters was looking from the aspects writing (Content, Organization, Vocabulary, Grammar, and Mechanic).

Table 1

\begin{tabular}{clcccccc}
\hline No & Method & Content & Organization & Vocabulary & Grammar & Mechanic & Average \\
\hline 1 & $\begin{array}{l}\text { Block } \\
\text { Style }\end{array}$ & 68.38 & 65.80 & 70.95 & 58.08 & 52.20 & 63.08 \\
2 & $\begin{array}{l}\text { Point by } \\
\text { Point }\end{array}$ & 86.02 & 88.60 & 86.02 & 68.01 & 67.64 & 78.38 \\
\hline
\end{tabular}

Based on the table above, the researcher conclude that the content of point by point (86.02) higher than block style (68.38), organization point by point (88.60) higher than block style (65.80), vocabulary point by point (86.02) higher than block style (70.95), grammar point by point (68.01) higher that block style (58.08, and also mechanic point by point (67.64) higher than block style $(52,20)$. So that the average score of point by point method (78.38) higher than block style method (63.08)

The questionnaire from both of the method are 20 items, the descriptive data shown from this table:

Table 2

Block Style Method

\begin{tabular}{|l|r|r|r|r|r|}
\hline & $\begin{array}{c}\text { StronglyAgr } \\
\text { ee }\end{array}$ & Agree & Undecide & Disagree & $\begin{array}{c}\text { StronglyDisa } \\
\text { gree }\end{array}$ \\
\hline $\mathrm{N} \quad$ Valid & 20 & 20 & 20 & 20 & 20 \\
Mean Missing & 0 & 0 & 0 & 0 & 0 \\
Std. Error of & 17,7500 & 31,0000 & 35,8500 & 15,1000 & 3,2000 \\
Mean & 2,91265 & 4,27354 & 3,38205 & 2,53595 & 1,03007 \\
Std. Deviation & 13,02578 & 19,11186 & 15,12501 & 11,34112 & 4,60663 \\
\hline
\end{tabular}

From this table, the mean score of strongly agree is 17.75 with standard deviation is 13.02 , the mean score of agree is 31.00 with standard deviation is 19.11 , the mean score of undecide is 35.85 with standard deviation is 3.38 , the mean score of disagree is 15.10 with standard deviation is 11.34 , and the mean score of strongly disagree is 3.20 with standard deviation is 4.60. Based on the statistic above, it means most of the students took undecided from the block style method questionaire. 
Table 3

Point by Point Method

\begin{tabular}{|l|r|r|r|r|r|}
\hline & $\begin{array}{c}\text { StronglyAgr } \\
\text { ee }\end{array}$ & Agree & Undecide & Disagree & $\begin{array}{c}\text { StronglYDis } \\
\text { agree }\end{array}$ \\
\hline N $\quad$ Valid & 20 & 20 & 20 & 20 & 20 \\
Mean & 0 & 0 & 0 & 0 & 0 \\
Std. Error of & 26,0000 & 37,0000 & 30,7500 & 10,7000 & 3,9500 \\
Mean & 4,59691 & 5,86784 & 2,21820 & 3,18970 & 1,27625 \\
Std. Deviation & 20,55801 & 26,24179 & 9,92008 & 14,26479 & 5,70757 \\
\hline
\end{tabular}

From this table, the mean score of strongly agree is 26.00 with standard deviation is 20.55 , the mean score of agree is 37.00 with standard deviation is 26.24 , the mean score of undecide is 30.75 with standard deviation is 9.92 , the mean score of disagree is 10.70 with standard deviation is 14.26 , and the mean score of strongly disagree is 3.95 with standard deviation is 5.70. Based on the statistic above, it means most of the students took agree from the point by point method questionaire.

\section{Hypothesis testing}

Based on the result of the research, the writer investigates that there is a significant difference between The Use of Block Style Method and Point by Point Method onThe Writing Ability of Level 2 Students of Language Center of UIN Suska Riau.

\section{Discussion}

After doing these research, the writer found some difference of using block style and point by point method on writing ability of level 2 students of Language Center of UIN Suska Riau.

The difference of the strategy are in the following:

- The students more understand of concept and procedure of point by point method than the concept and procedure of block style method.

- The students are very interested when the teacher asked them to write about a topic by using point by point method.

- The students easy to generating idea in writing by using point by point method.

- The students easy to control and develop idea in writing by using point by point method

\section{CONCLUSION}

The research finding could be concluded that there was a significant difference by using block style method and point by point method toward the students' ability in writing at language center of UIN SUSKA RIAU. It can be recognized that the score of sig.(2tailed) was smaller than score of $\mathrm{H}_{0}$. Therefore, the null hypothesis was rejected and the alternative hypothesis was accepted $(0.000<0.005)$. It mean that there is a significant difference between The Use of Block Style Method and Point by Point Method on the Writing Ability of Level 2 Students of Language Center of UIN Suska Riau. At last, it shows that Point by point was better than the implementation of Block Style Method.

The implication of the research upon the data analysis as described beforehand, the research findings were then interpreted from different points of view. The findings of the study illustrated that there was a significant 
difference between The Use of Block Style Method and Point by Point Method on the Writing Ability of Level 2 Students of Language Center of UIN Suska Riau; and Point by point was better than the implementation of Block Style Method. The finding of this study was also supported Colorin Colorado (2007) to acknowledge that there were many types of effective writing instruction used in classrooms today, including process writing, graphic organizers as writing planning tools, vocabulary stretchers, etc... and all of those were beneficial to ELL students. Furthermore, the purpose focused on a few writing activities that was particularly useful when working with students with a wide-range of English language skills.

\section{REFERENCES}

Baker, Mark. 2011. "Three Components of Writing Skills". (retrieved on January 24, 2015), http://everypageisonepage.com/20 11/09/15/three-components-ofwriting-skill/.

Baygell, Ruth. 2003. Education Program Newsweek: Essay Writing Step-by-Step. New York: Simon \& Schuster.

Coffin, Caroline, et al. 2003. Teaching Academic Writing: A Toolkit for Higher Education. New York: Routledge.

Creswell, John. Wl. 2008. Educational Research Planning, Conducting, and Evaluating Quantitative and Qualitative Research. New Jersey: Prentice Hall.

Division of Simon and Schuster. 1978. Writing Clear Paragraph. Prentice-hall. Englewood cliffs, New jersey.
Hadley, A. Omaggio. 1993. Teaching Language in context. Boston: Heinle \& Heinle.

Hartono, M.Pd. Statistik Untuk Pendidikan. Yogyakarta : Pustaka Pelajar Offset.

Hornby. AS et al. 1974. The advenced learners dictionary of current English. London. Oxford University of Arizona.

Hughey, Jane B. 1983. Teaching ESL Composition Principles and tecniques. Newbury House Publishers.

Hornby, A S. 1995. Advanced Learners Dictionary and Current English Oxford. Oxford: Oxford University.

http://guruw.wordexpress.com/caategor y/kurikulum-sekolah.

http://www.ascd.org/publications/books /110126/chapters/Section-1@_ Why-Compare-\$Contrast\%C2\%A2.aspx.

http://www.readwritethink.org/files/reso urces/interactives/compcontrast/m ap.html.

Kalayo Hasibuan and Muhammad Fauzan. 2007. Teaching English as a foreign language. Pekanbaru: Alaf Riau Graha UNRI Press.

Kaplan,Robert.1993. Teaching ESL Writing. United states of America: prentice Hall regents.

Langan, John. 1986. College Writing Skill, with Reading. New York: Mcgraw Hill.

Mary Underwood. 1989. Teaching Listening: Longman Handbooks for Language Teachers. New York: Longman Inc.

Morris, William. 1981. The American Heritage Dictionary of the 
English Language. U.S.A:
Houghton Mifflin Company.

M, Syafi'i S. 2007. From Paragraphs to A Research Report: A Writing of English for Academic Purpose.
Pekanbaru: Lembaga Bimbingan Belajar Syaf Intensive.

Reid, Joy M. 1993. Teaching ESL Writing. University of Wyoming. New Jersey: Prentice Hall Regents. 
